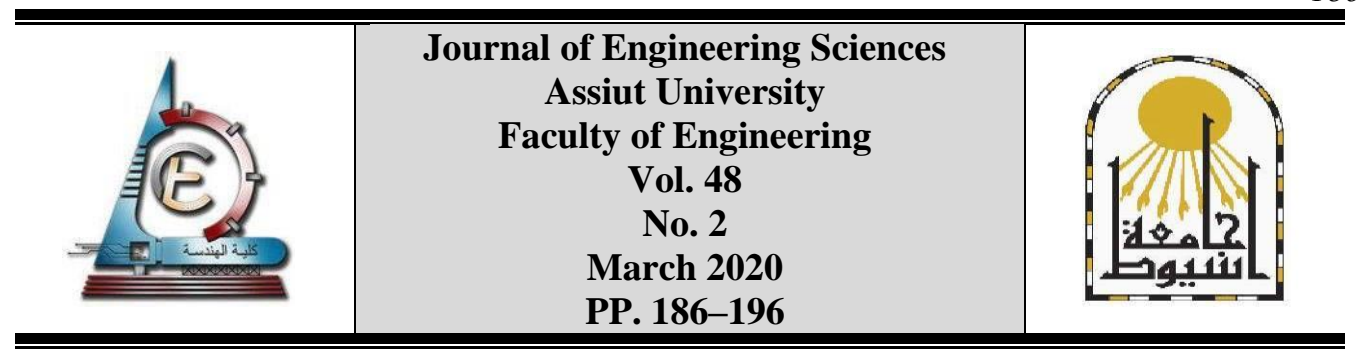

\title{
FLOW CHARACTERISTICS OF OPEN CHANNELS WITH FLOATING VEGETATION
}

\author{
Hassan I. Mohamed ${ }^{1}$, Alaa-Eldin M. Abd-Elaal ${ }^{2}$, Adel A.Mahmoud ${ }^{3,}{ }^{*}$ \\ ${ }^{1}$ Civil Eng. Department, Assiut University \\ ${ }^{2,3}$ Civil Eng. Department, Sohag University
}

Received 19 August 2019; Accepted 8 September 2019

\begin{abstract}
Floating vegetation (Water hyacinth) causes many problems in waterways where it retards flow movement and changes flow structure. In this study the impact of water hyacinth on flow behavior in open channels was investigated in a laboratory flume. Water hyacinth was harvested from natural streams. Four different vegetation densities, three different vegetation root depths and three different vegetation zone lengths were used for smooth and rough channel bed. The case without water hyacinth was considered as comparative case. The water surface profiles for all cases were investigated. Results show that in the presence of water hyacinth water surface profile rises before vegetation zone then goes down until reaches to normal water surface. Results also show that water surface profile influenced by vegetation density, vegetation root depth, and vegetation zone length and bed roughness. Also the effect of vegetation parameters (density, root depth, zone length) on heading up, discharge and equivalent Manning's roughness coefficient was investigated and it is found that these parameters have a great effect on it. Multiple regression equations based on the dimensional analysis theory were deduced to calculate heading up, discharge and equivalent Manning's roughness coefficient.
\end{abstract}

Keywords: heading up, vegetation, Manning's roughness coefficient, water hyacinth.

\section{Notations}

$F_{e}=$ Froude number

$\mathrm{g}=$ gravity of acceleration.

$\mathrm{K}_{\mathrm{b}}=$ bed roughness and it is the soil- particle size at which $90 \%$ is passing.

$\mathrm{K}_{\mathrm{v}}=$ vegetation root depth.

$\mathrm{L}_{\mathrm{v}}=$ vegetation length.

$\mathrm{n}_{\mathrm{eq}}=$ equivalent Manning's roughness coefficient of channel cross section at vegetation zone.

$\mathrm{n}_{\mathrm{O}}=$ Manning's roughness coefficient of channel cross section for case of no vegetation.

$\mathrm{Q}=$ flow rate passes through the channel.

$R_{n}=$ Reynolds number

$\mathrm{U}=$ mean velocity at depth equal $\mathrm{Y}_{\mathrm{o}}$.

$Y_{o}=$ water depth before vegetation zone (free water surface + heading up).

$\lambda_{\mathrm{v}}=$ vegetation density.

$\Delta \mathrm{Y}=$ the heading up.

$\rho=$ water density. 


\section{Introduction}

Floating vegetation is commonly appeared in rivers, lakes and wetland marshes, [1]. Suspended vegetation can be divided into two groups, rooted vegetation with floating leaves (pondweeds, water lilies and American lotus) and free-floating leaves with developed or underdeveloped roots (Water hyacinth, common bladderworts, and duckweeds) [2]. The presence of such rough covers (ice jam, floating vegetation and floating debris) changes the flow structure and velocity distribution, [3], [4]. Water hyacinth has spread widely in all rivers and water bodies and its ability to adjust and reproduce causes many problems in waterways with related to both hydraulic and water quality issues [5]. Several studies regarding the open-channel flow with aquatic vegetation (submerged or emergent or floating) have been performed. For example, [6] investigated flow resistance in vegetated streams. He presented a new theory which explains the non-linear relationship between channel resistance and the ratio of the channel occupied by vegetation. [7] investigated the influence of grass blades on the flow resistance in small and large channels. He concluded that Manning's coefficient decreases when flow depth increases and drag coefficient value highly correlated to the vegetation height, and follows a power law relationship. [8] investigated the flow through double layer rigid vegetation. He found that the interaction of high and low momentum fluids causes the flow to fold, and creates strong vortices within each mixing layer. [9] studied flow characteristics of partially vegetated trapezoidal channel crosssection with flexible vegetation. He developed a method for predicting the total conveyance of trapezoidal channel cross-section with varying roughness in perimeter due to growth of flexible vegetation. Also, a regression relationships were developed for computing the equivalent Manning coefficient for vegetated channels. [10] adopted a three-layer model on basis of mixing length theory to simulate the flow structure of open channel flow covered by floating rigid vegetation. [11] Investigated Manning's and drag coefficients for flexible submerged vegetation, they found that Manning's coefficient decreased with the increasing in average velocity. In this study, effect of water hyacinth on water surface profile is investigated; laboratory experiments were conducted in a flume covered with water hyacinth. The vegetation length $\left(\mathrm{L}_{\mathrm{v}}\right)$, vegetation root depth $\left(\mathrm{K}_{\mathrm{v}}\right)$, vegetation density $\left(\lambda_{\mathrm{v}}\right)$ and bed roughness $\left(\mathrm{K}_{\mathrm{b}}\right)$ were set up as the control parameters. The dimensional analysis was used to derive some equations to calculate heading up in water surface profile, discharge and equivalent roughness in open channel due to the presence of water hyacinth.

\section{Experimental work}

The experiments were carried out in water circulating rectangular flume with dimension (10 m long, $0.3 \mathrm{~m}$ wide and $0.3 \mathrm{~m}$ deep) which is located in the Irrigation and Hydraulic Laboratory of Engineering Department, Assiut University, Egypt. At the exist section of the flume, a hinged variable sloping tailgate was installed and at the upstream end a head tank is supplied to control the water. The studied vegetation shown in figure (1) covered $3 \mathrm{~m}$ long section at middle of the flume. The laboratory flume which used in the experiments is shown in figure (2). The plants (water hyacinth) were collected from natural streams. To prevent plants from moving with flow, a wooden frame with three hollow rectangles have dimensions $0.29 \mathrm{~m}$ wide and $1.00 \mathrm{~m}$ long was used, these rectangles frames was divided to small equal rectangles by a fine cotton thread. Plants were placed inside these small rectangles and all were fixed over the flume using a fine cotton thread and the system suspended $2 \mathrm{~cm}$ above the water surface as shown in figure (3) to prevent any retardation to flow by the system . To study the effect of vegetation density, 
vegetation root depth, vegetation length and bed roughness on the water surface profile, heading up, discharge and equivalent roughness, the experimental runs were carried out with four vegetation densities $\left(\lambda_{v}=30,60,90,120\right.$ pieces $\left./ \mathrm{m}^{2}\right)$, three vegetation root depths $\left(K_{v}=1,3,5 \mathrm{~cm}\right)$, three vegetation lengths $\left(L_{v}=1,2,3 \mathrm{~m}\right)$ with smooth and rough channel bed. The vegetation is placed at $3.00 \mathrm{~m}$ away from the beginning of the flume as shown in figure (2). Table (1) shows the range of variables used in this study. The water depth was measured by a point gauge for each run at different distances along the flume length. The measurements started $1.00 \mathrm{~m}$ before vegetation and ended $1.50 \mathrm{~m}$ after vegetation zone. Four discharges $(10,12,14,16 \mathrm{~L} / \mathrm{s})$ were passed through the flume.

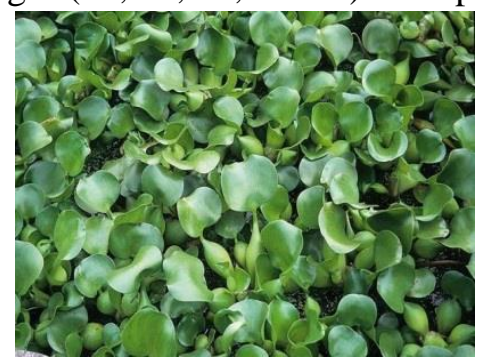

Fig. 1. Water Hyacinth used in the study (Eichhornia crassipes).

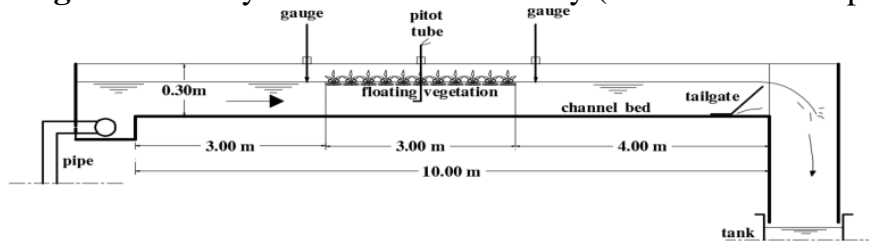

Fig. 2. Experimental flume.

Table 1.

Range of variables used in the study.

\begin{tabular}{|l|c|l|l|l|l|}
\hline Parameter & Symbol & \multirow{2}{*}{ Units } & \multicolumn{2}{l|}{ Values } & \multicolumn{2}{l|}{ Range } \\
\cline { 5 - 6 } & & & & From & To \\
\hline Water Depth & $Y_{o}$ & $\mathrm{~cm}$ & varied & 17 & 20.7 \\
\hline Discharge & $\mathrm{Q}$ & $\mathrm{L} / \mathrm{s}$ & varied & 10 & 16 \\
\hline Vegetation Density & $\lambda_{v}$ & Pieces $/ \mathrm{m}^{2}$ & varied & 30 & 120 \\
\hline Vegetation Length & $L_{v}$ & $\mathrm{~m}$ & $1,2,3$ & 1 & 3 \\
\hline Vegetation Root Length & $K_{v}$ & $\mathrm{~cm}$ & $1,3,5$ & 1 & 5 \\
\hline Bed Roughness height & $K_{b}$ & $\mathrm{~mm}$ & Smooth & - & - \\
& & & 11.7 & & \\
\hline
\end{tabular}

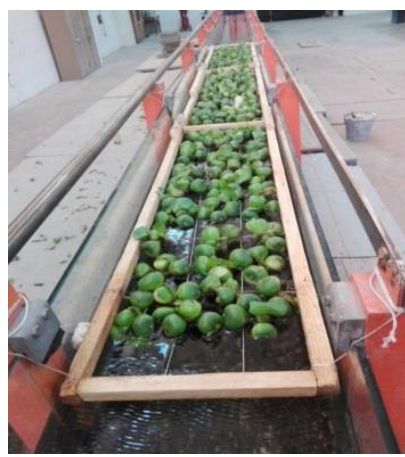

Fig. 3. the system which used in vegetation hanging. 


\section{Theoretical approach}

The method of dimensional analysis can serve best in absence of a theoretical approach which seems in our problem very complicated. The success of this method depends on the prescience in selecting the governing parameters. The variables used for dimensional analysis are chosen to represent all the parameters involved in the problem under consideration. The general functional relationship for these variables is given in the following form:

$$
\Delta Y \text { or } Q \text { or } n_{e q}=\emptyset\left(\lambda_{v}, L_{v}, K_{v}, K_{b}, Y_{o}, U, \rho, g, \mu, n_{o}\right)
$$

Where $\Delta \mathrm{Y}$ is magnitude of rising in water surface from free water surface, $\mathrm{Q}$ is discharge, $n_{e q}$ is equivalent manning roughness coefficient of channel cross section at vegetation zone, $\lambda_{v}$ is vegetation density, $L_{v}$ is vegetation length, $K_{v}$ is vegetation root depth, $K_{b}$ is bed roughness and defined by bed soil- particle size at which $90 \%$ is passing, $\mathrm{Y}_{\mathrm{o}}$ is water depth before vegetation zone (free water surface + heading up), $\mathrm{U}$ is flow velocity, $\rho$ is flow density, $g$ is gravity of acceleration, $\mu$ kinematic viscosity, $n_{o}$ is manning roughness coefficient of channel for case of no vegetation.

Applying the Buckingham's " $\pi$ " theorem, the following non-dimensional groups will results:

$$
\frac{\Delta \mathrm{Y}}{\mathrm{Y}_{\mathrm{o}}} \text { or } \frac{\mathrm{Q}}{\mathrm{g}^{0.5} \mathrm{Y}_{\mathrm{o}}^{2.5}} \text { or } \frac{\mathrm{n}_{\mathrm{eq}}}{\mathrm{n}_{\mathrm{o}}}=\varnothing\left(\lambda_{\mathrm{v}} * \mathrm{Y}_{\mathrm{O}}^{2}, \frac{\mathrm{K}_{\mathrm{v}}}{\mathrm{Y}_{\mathrm{O}}}, \frac{\mathrm{L}_{\mathrm{V}}}{\mathrm{Y}_{\mathrm{O}}}, \frac{\mathrm{K}_{\mathrm{b}}}{\mathrm{Y}_{\mathrm{O}}}, \frac{\mathrm{U}}{\sqrt{\mathrm{g} \mathrm{Y}_{\mathrm{O}}}}, \frac{\rho \mathrm{U} \mathrm{Y}_{\mathrm{O}}}{\mu}\right)
$$

Eqn. 2 was used in analysis correlation between vegetation variables (density, root depth and zone length) and heading up, discharge and equivalent manning's roughness coefficient.

\section{Results and discussions}

In this section the results of experimental program are discussed. The influence of vegetation density, vegetation root depth, vegetation infected length and bed roughness on vertical velocity profile, water surface profile, heading up, discharge, equivalent manning's roughness coefficient and vegetation drag force are analyzed.

\subsection{Water surface profile}

\subsubsection{Effect of vegetation density on water surface profile}

Figure (4) illustrates the effect of vegetation density on water surface profile for the same vegetation root depth and the same vegetation infected length for case of smooth bed. As shown in the figure water surface rises before vegetation zone then goes down through vegetation zone and goes back to normal water surface after vegetation zone. This means that vegetation zone works as an obstruction to the flow in the channel.

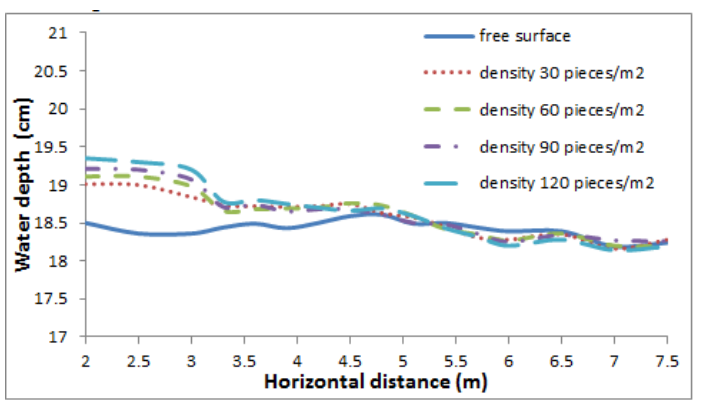

Fig. 4. water surface profile for vegetation root depth $=5 \mathrm{~cm}$, vegetation zone length $=3 \mathrm{~m}$ and different vegetation densities, case of smooth bed channel 


\subsubsection{Effect of vegetation root depth on water surface profile}

Figure (5) illustrates effect of vegetation root depth on water surface profile for same vegetation density and vegetation length for case of smooth bed. It is clear from the figure that vegetation root depth has the same effect of vegetation density on water surface profile.

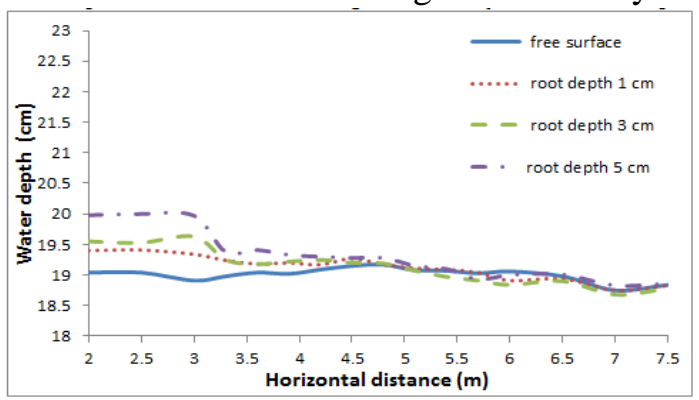

Fig. 5. water surface profile for vegetation density $=120$ pieces $/ \mathrm{m}^{2}$, vegetation zone length $=3$ $\mathrm{m}$ and different vegetation root depths, case of smooth bed channel

\subsubsection{Effect of vegetation zone length on water surface profile}

Figure (6) shows the effect of vegetation zone length on water surface profile for same vegetation density and vegetation root depth for smooth bed case. The figure shown that also vegetation zone length has the same effect of vegetation density and vegetation root depth on water surface profile.

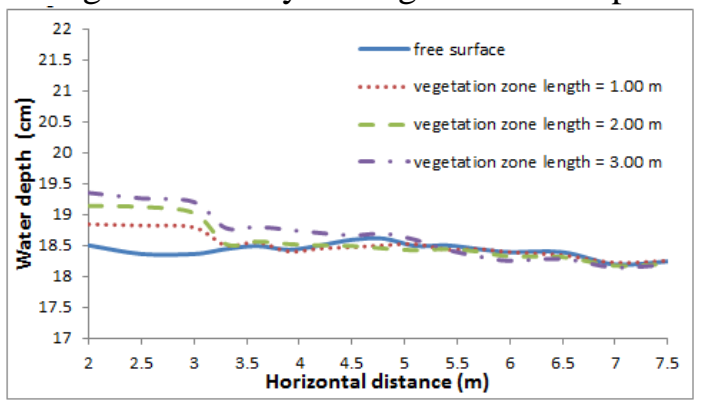

Fig. 6. water surface profile for vegetation density $=120$ pieces $/ \mathrm{m}^{2}$, vegetation Root depth $=5$ $\mathrm{cm}$ and different vegetation zone lengths, case of smooth bed channel

\subsubsection{Effect of bed roughness on water surface profile}

For rough bed, effect of vegetation density, vegetation root depth and vegetation zone length on water surface profile have been studied. Figures $(7,8,9)$ illustrate the effect of vegetation density, vegetation root depth and vegetation zone length on water surface profile in the case of rough bed. It is found from the figures that the mentioned variables have the same behavior as in the case of smooth bed except that in the case of rough bed the magnitude of rising in water surface is bigger than its value in the case of smooth bed.

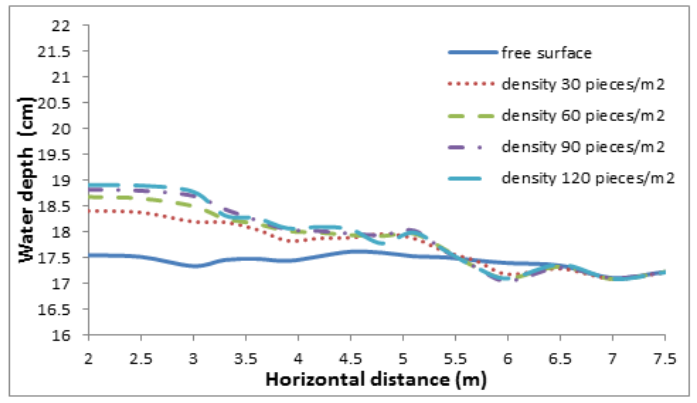

Fig.7. water surface profile for vegetation root depth $=5 \mathrm{~cm}$, vegetation zone length $=3$ $\mathrm{m}$ and different vegetation densities, case of rough bed channel 


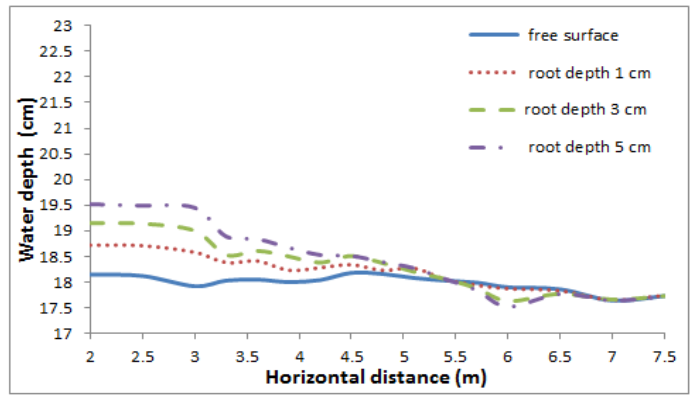

Fig. 8. water surface profile for vegetation density $=120$ pieces $/ \mathrm{m}^{2}$, vegetation zone length $=3$ $\mathrm{m}$ and different vegetation root depths, case of rough bed channel

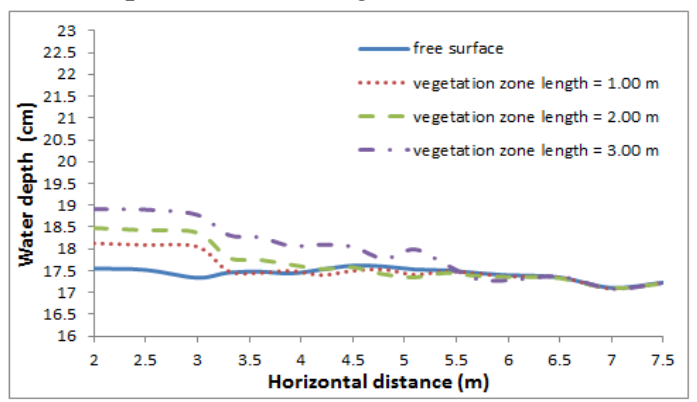

Fig. 9. water surface profile for vegetation density $=120$ pieces $/ \mathrm{m}^{2}$, vegetation Root depth $=5$ $\mathrm{cm}$ and different vegetation zone lengths, case of rough bed channel

\subsection{Effect of infected area on heading up}

This part discusses the effect of vegetation variables (vegetation density, vegetation root depth and vegetation zone length) on the magnitude of rising up in water surface from free water surface (heading up $\Delta Y)$. In Fig. (10) ratio of heading up to water depth $\left(\Delta Y / Y_{o}\right)$ was drawn versus vegetation density as dimensionless term $\left(\lambda_{v} * Y o^{2}\right)$ for different vegetation zone lengths and vegetation root depth $=1 \mathrm{~cm}$. It is clear from the figure that when vegetation density increases the ratio $\left(\Delta \mathrm{Y} / Y_{o}\right)$ increases for all vegetation zone lengths.

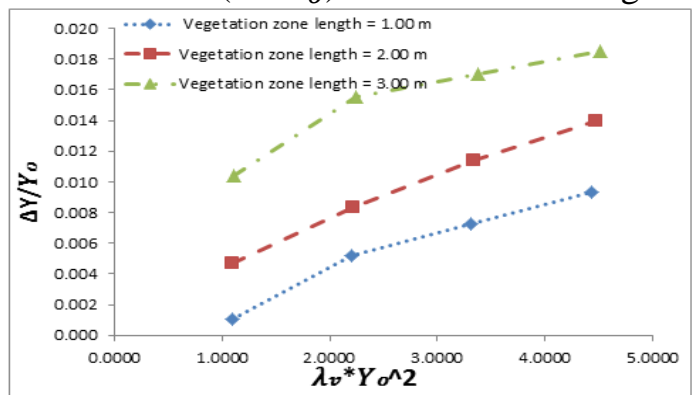

Fig. 10. variation of dimensionless heading up with dimensionless vegetation density for different vegetation zone lengths and vegetation root depth $=1 \mathrm{~cm}$.

The same results are found when the ratio $\left(\Delta \mathrm{Y} / Y_{o}\right)$ was drawn versus the ratio of vegetation root depth to water depth $\left(K_{v} / Y_{o}\right)$ for different vegetation zone lengths and vegetation density $=30$ pieces $/ \mathrm{m}^{2}$ as shown in Fig.(11) and when the ratio $\left(\Delta \mathrm{Y} / Y_{o}\right)$ was drawn versus the ratio of vegetation zone length to water depth $\left(L_{v} / Y_{o}\right)$ for different vegetation densities and vegetation root depth $=1 \mathrm{~cm}$ as shown in figure (12). 


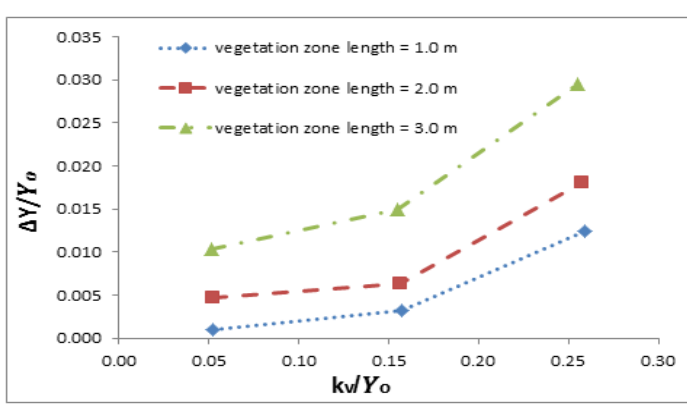

Fig. 11. variation of dimensionless heading up with the ratio of vegetation root depth to water depth for different vegetation zone lengths and vegetation density $=30$ pieces $/ \mathrm{m}^{2}$.

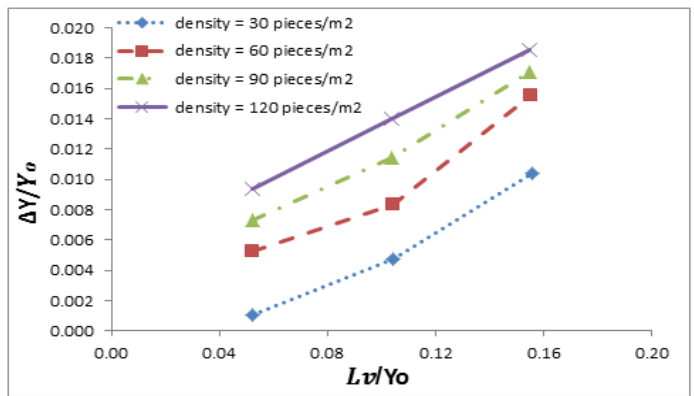

Fig. 12. variation of dimensionless heading up with the ratio of vegetation zone length to water depth for different vegetation densities and vegetation root depth $=1 \mathrm{~cm}$.

Figs. 10, 11 and 12 show a correlation between the independent and dependent parameter indicated in Eqn. 2. So a multiple linear regression analysis is used to derive an equation to calculate the heading up using excel regression tool as follows:

For smooth bed the following equation is deduced with a coefficient of determination $R^{2}=0.94$.

$$
\frac{\Delta Y}{Y_{o}}=0.11+0.0005 \frac{L_{v}}{Y_{o}}+0.032 \frac{K_{v}}{Y_{o}}+0.0013 \lambda_{v} Y_{o}{ }^{2}-2.38 F_{e}-6.59 \times 10^{-6} R_{n}
$$

For rough bed the following equation is deduced with a coefficient of determination $\quad R^{2}=0.99$.

$$
\frac{\Delta Y}{Y_{o}}=0.88+4.53 \times 10^{-5} \frac{L_{v}}{Y_{o}}+0.0027 \frac{K_{v}}{Y_{o}}+0.0001 \lambda_{v} Y_{o}{ }^{2}-1.22 F_{e}-10 \frac{k_{b}}{Y_{o}}
$$

\subsection{Effect of infected area on discharge}

With increasing in land slope and increasing in streamlining of the vegetation, flow became less retarded and when flow depth increases flow was more retarded due to submergence of more rough elements with flow depth, [12]. The mean and turbulent flow structure in channels influenced by aquatic vegetation and thus affects sediment and transport of it, [13]. In Fig. (13) water discharge which passes through the flume as a dimensionless ratio $\left(\mathrm{Q} / g^{0.5} Y^{2.5}\right)$ is plotted versus vegetation density as dimensionless term $\left(\lambda_{v} * Y o^{2}\right)$ for different vegetation zone lengths and vegetation root depth $=3 \mathrm{~cm}$. It is clear from this figure that the water discharge decreases with the increase of vegetation density for all vegetation zone lengths. 


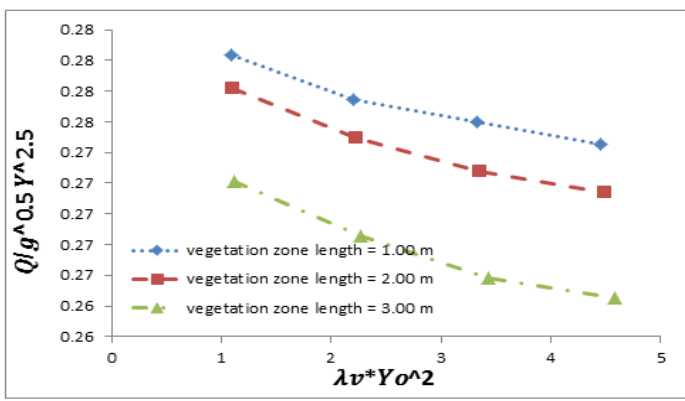

Fig. 13. variation of dimensionless water discharge ratio with dimensionless vegetation density for different vegetation zone length and vegetation root depth $=3 \mathrm{~cm}$.

Also the ratio of vegetation root depth to water depth $\left(K_{v} / Y_{o}\right)$ and the ratio of vegetation zone length to water depth $\left(L_{v} / Y_{o}\right)$ have the same effect of dimensionless vegetation density $\left(\lambda_{v} * Y o^{2}\right)$ on dimensionless water discharge $\left(\mathrm{Q} / g^{0.5} Y o^{2.5}\right)$ when plotted against each other as shown in Figs. 14 and 15.

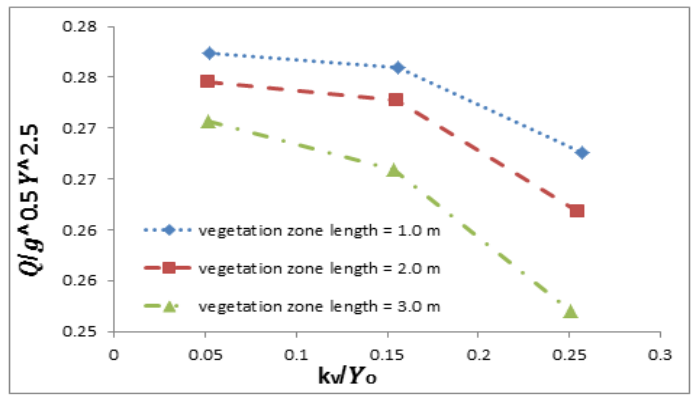

Fig. 14. Variation of dimensionless water discharge with the ratio of vegetation root depth to water depth for different vegetation zone length and vegetation density $=90$ pieces $/ \mathrm{m}^{2}$.

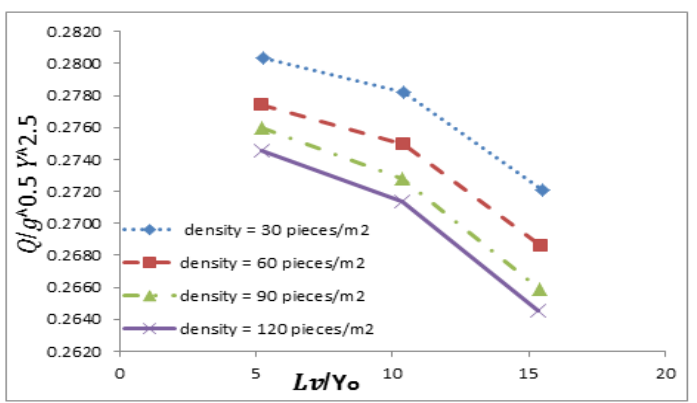

Fig. 15. variation of dimensionless water discharge ratio with the ratio of vegetation zone length to water depth for different vegetation densities and vegetation root depth $=3 \mathrm{~cm}$.

A multiple linear regression analysis is used to deduce an equation for calculating the discharge as follows:

For smooth bed the following equation is deduced with a coefficient of determination $\quad R^{2}=0.98$.

$\frac{Q}{g^{5} Y_{O^{2.5}}}=0.16-0.00082 \frac{L_{v}}{Y_{o}}-0.052 \frac{K_{v}}{Y_{o}}-0.0023 \lambda_{v} Y_{o}{ }^{2}-2.79 \times 10^{-6} R_{n}$

For rough bed the following equation is deduced with a coefficient of determination $\quad R^{2}=0.89$.

$\frac{Q}{g^{5} Y_{o} o^{2.5}}=0.83-0.003 \frac{L_{v}}{Y_{o}}-0.15 \frac{K_{v}}{Y_{o}}-0.006 \lambda_{v} Y_{o}{ }^{2}-7.42 \frac{k_{b}}{Y_{o}}$ 


\subsection{Effect of infected area on Manning's roughness coefficient}

Manning's roughness coefficient is affected by the geometry changes between sections, the vegetation in the channel, the bed roughness and the channel obstructions, [14]. In Fig. (16) Values of dimensionless equivalent manning's roughness coefficient $\left(n_{e q} / n_{o}\right)$ is plotted versus dimensionless vegetation density for different vegetation lengths and vegetation root depth $=5 \mathrm{~cm}$. As shown in the figure when dimensionless vegetation density increases the dimensionless equivalent manning's roughness coefficient increases.

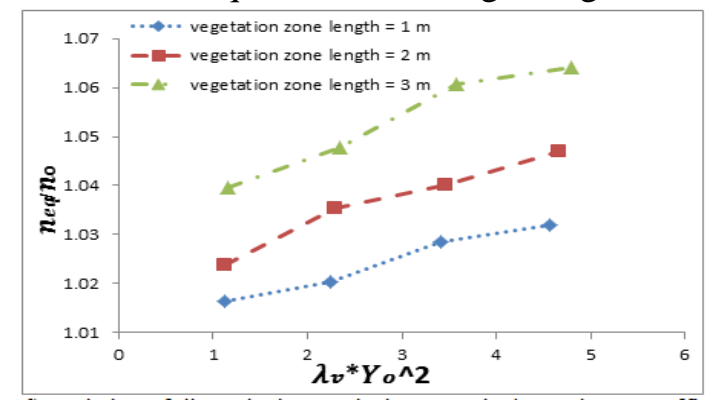

Fig. 16. variation of dimensionless equivalent manning's roughness coefficient with dimensionless vegetation density for different vegetation zone lengths and vegetation root depth $=5 \mathrm{~cm}$.

The same trend occurs between dimensionless equivalent manning's roughness coefficient $\left(n_{e q} / n_{o}\right)$ and the ratio of vegetation root depth to water depth $\left(K_{v} / Y_{o}\right)$ and the ratio of vegetation zone length to water depth $\left(L_{v} / Y_{o}\right)$ when they plotted against each other. Figs. 17 and 18 illustrate this relationship between them.

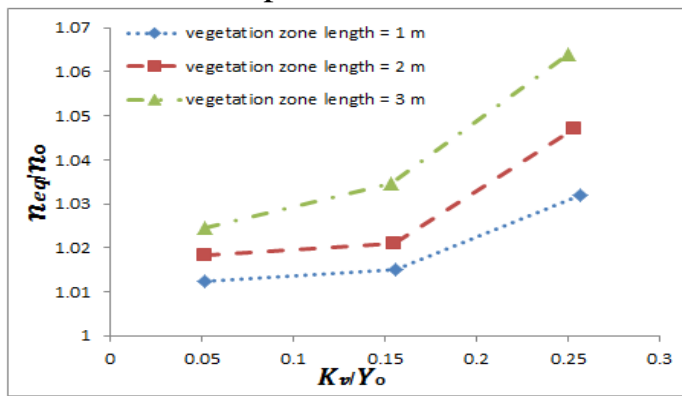

Fig. 17. variation of dimensionless equivalent manning's roughness coefficient with the ratio of vegetation root depth to water depth for different vegetation zone length and vegetation density $=120$ pieces $/ \mathrm{m}^{2}$.

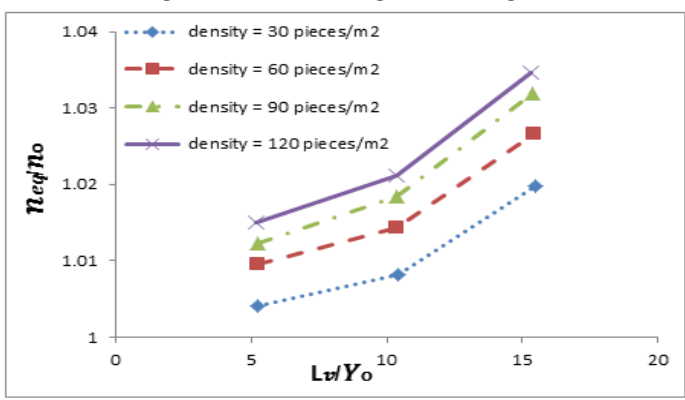

Fig. 18. variation of dimensionless equivalent manning's roughness coefficient with the ratio of vegetation zone length to water depth for different vegetation densities and vegetation root depth $=3 \mathrm{~cm}$.

An equation to calculate equivalent manning's roughness coefficient was deduced using multiple linear regression analysis as follows: 
For smooth bed the following equation is deduced with a coefficient of determination $\quad R^{2}=0.93$.

$\frac{n_{e q}}{n_{o}}=1.23+0.0008 \lambda_{v} Y_{o}{ }^{2}+0.015 \frac{k_{v}}{Y_{O}}+6.9 \times 10^{-5} \frac{L_{v}}{Y_{O}}-4.38 \mathrm{Fe}+1.2 \times 10^{-5} R_{n}$

For rough bed the following equation is deduced with a coefficient of determination $R^{2}=0.99$.

$$
\frac{n_{e q}}{n_{o}}=2.28-0.00012 \lambda_{v} Y_{o}^{2}-0.0031 \frac{k_{v}}{Y_{O}}-4.9 \times 10^{-5} \frac{L_{v}}{Y_{O}}-1.79 \mathrm{Fe}-14.5 \frac{k_{b}}{Y_{o}}
$$

\section{Conclusions}

In this study, a series of laboratory experiments were conducted to study the effect of water hyacinth on flow characteristics. The main conclusions drawn from this study can be summarized as follows;

1. Vegetation zone works as an obstruction to the flow in the channel where due to the presence of vegetation in channel, water surface rises before vegetation zone then goes down through vegetation zone and goes back to normal water surface after vegetation zone.

2. Due to bed roughness the magnitude of rising in water surface before vegetation zone becomes bigger than that in case of smooth bed for the same cases of presence of vegetation.

3. The equivalent Manning's roughness coefficient of channel increases by increasing vegetation density, vegetation root depth and vegetation zone length.

4. The heading up increases by increasing vegetation density, vegetation root depth and vegetation zone length.

5. The flow rate through channel decreases by increasing vegetation density, vegetation root depth and vegetation zone length.

6. Multiple regression analysis equations based on the dimensional analysis concept were deduced for computing the equivalent manning's roughness coefficient, heading up and flow rate through channel.

\section{REFERENCES}

[1] Bocchiola, D., Catalano, F., Menduni, G., \& Passoni,G. (2002). An analytic numerical approach to the hydraulics of floating debris in river channels. Journal of Hydrology, 269,65-78. Retrieved From.

[2] Folkard, A. M. (2011). Flow regimes in gaps within stands of flexible vegetation: Laboratory flume simulations. Environmental Fluid Mechanics, 11(3), 289-306.

[3] Teal, M. J., Ettema, R., \& Walker, J. F. (1994). Estimation of Mean Flow Velocity in IceCovered Channels. Journal of Hydraulic Engineering, 120(12), 1385-1400.

[4] Smith, B. T., \& Ettema, R. (1997). Flow Resistance in Ice-Covered Alluvial Channels. Journal of Hydraulic Engineering, 123(7), 592-599.

[5] Saknimit, 1976. Study of the Productivity of Water Hyacinth. M.Sc. Thesis. Chulalongkorn University, Bangkok, Thailand.

[6] Green, J. C. (2005). Modelling flow resistance in vegetated streams: Review and development of new theory. Hydrological Processes, 19(6), 1245-1259.

[7] Wilson, C. A. M. E. (2007). Flow resistance models for flexible submerged vegetation. Journal of Hydrology, 342(3-4), 213-222.

[8] Liu, D., Diplas, P., Hodges, C. C., \& Fairbanks, J. D. (2009). Hydrodynamics of flow through double layer rigid vegetation. Geomorphology, 116(3-4), 286-296.

[9] Mohamed, H. I. (2010). Flow Characteristics of Partially Vegetated Trapezoidal Channel Cross-Section.14th Int. Water Techn. Conf., IWTC14, Cairo, Egypt, pp. 1117-1129.

[10] Huai, W., Hu, Y., Zeng, Y., \& Han, J. (2012). Velocity distribution for open channel flows with suspended vegetation. Advances in Water Resources, 49, 56 - 61. 
[11] Khamaruzam W., Y., Muhammad, M., M., Muhammad,R., M., Nor, A., Z., \& Aminuddin, G., A. (2017). Analysis of Manning's and Drag Coefficients for Flexible Submerged Vegetation. IOP Conference Series: Materials Science and Engineering, 216(1).

[12] Moghadam, M.F. (2006). Effects of Land Slope and Flow Depth on Retarding Flow in Non-submerged Vegetated Lands. Journal of Agronomy, 5(3), 536-540.

[13] Nepf, H. M., \& Vivoni, E. R. (2000). Flow structure in depth-limited, vegetated flow. Journal of Geophysical Research: Oceans, 105(C12), 28547-28557.

[14] De Doncker, L., Troch, P., Verhoeven, R., Bal, K., Meire, P., \& Quintelier, J. (2009). Determination of the Manning roughness coefficient influenced by vegetation in the river Aa and Biebrza river. Environmental Fluid Mechanics, 9(5), 549-567.

\section{خصائص التذفق للقتوات المكثوفة ذات الحشائش الطافية}

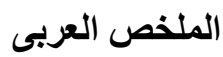

الحشائش الطافية (ورد النيل) تسبب العديد من المشاكل في المجاري المائية حيث تعوق حركة التدفق وتغير هيكله.

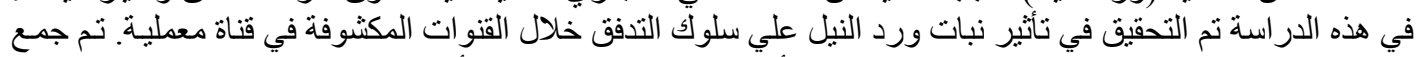

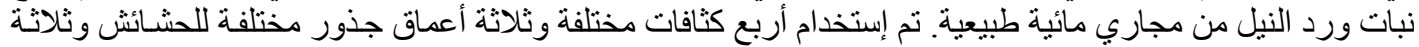

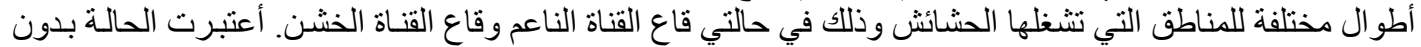

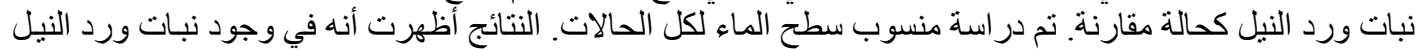

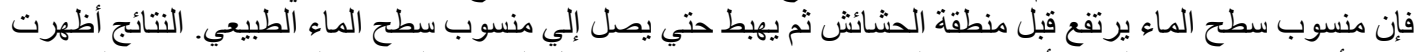

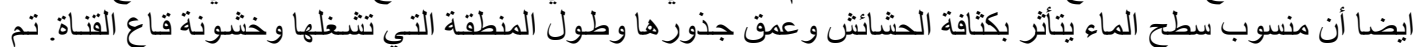

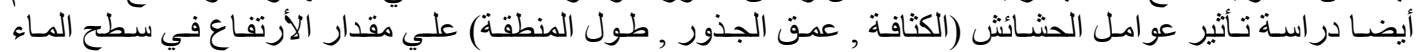

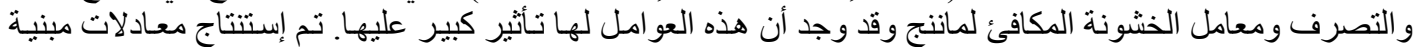

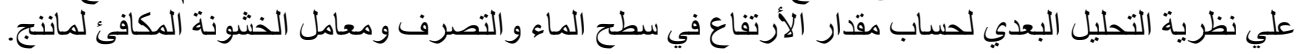

